\title{
The teaching of French in the French educational system: Obstacle or way to promote the plurilingualism of pupils?
}

\author{
La enseñanza del francés en el sistema educativo francés: ¿un obstáculo o un modo \\ de promover el plurilingüismo en los alumnos?
}

\section{Summary}

This paper proposes an in-depth on the legal and educational linguistic policy of the state that affect the everyday practice school French students. The allied French academic culture to the school culture are articulated to serve the construction of republican citizenship. This ideological construction, political and cultural affects students entering the use of French particularities (phonetic, semiotic or symbolic...) of its cultural, social status or family origin.

From a historical and legislative perspective the authors address the orientation of the teaching of French in the educational system as an obstacle to the integration of groups of students who do not fit the narrow linguistic-political patterns that the system imposes. And finally, from an applied perspective, explores the factors that can lead to the breakdown of monolingual system, moreover, is articulated as a cultural system of segregation and exclusion of class.

Keywords: Intercultural education, Linguistic and educational policies, plurilingual system, educative integration, allophones and francophones.

\section{Resumen}

Este artículo propone una reflexión en profundidad sobre las consecuencias jurídicas y pedagógicas de la política lingüística del estado que afectan en la práctica cotidiana escolar al alumnado francés. La cultura académica francesa aliada con la cultura escolar se articulan al servicio de la construcción de la ciudadanía republicana. Esta construcción ideológica, política y cultural afecta a los estudiantes que incorporan al uso de la lengua francesa particularidades propias (fonéticas, semióticas, simbólicas ...) de su entorno cultural, social o de su origen familiar.

Desde una perspectiva histórica y legislativa los autores abordan la orientación de la enseñanza de la lengua francesa en el sistema educativo como un obstáculo para la integración de los grupos de

\footnotetext{
NB: Academic rules and regulations are too many to be quoted in this article. Therefore we used asterisks to pinpoint notions referring to texts published in the national education official bulletin that can be found using search engines. In order to avoid a difficult reading, the main bibliographical and sitographical references of the used hypertext are gathered at the end of the article. As far as the examples are concerned, they come from the professional experience of the authors of this article.
} 
alumnado que no se ajustan a los estrechos patrones linguístico-políticos que el sistema impone. Y por último, desde una perspectiva aplicada, exploran los factores que pueden desembocar en la ruptura del sistema monolingüe que, además, se articula como un sistema de segregación cultural y de exclusión clasista.

Palabras clave: educación intercultural, usos culturales de la lengua, políticas educativas y lingüísticas, plurilingüísmo, integración educativa, alófonos y francófonos.

\section{Power of the national monolingual model}

French school today is far from developing, promoting or even simply acknowledging the multilingual skills of the pupils under its trust. The principles of The European charter on plurilingualism which states that the right to fully master one's own mother tongue is a fundamental freedom do not make any sense to the French academic tradition which most of the time seems to ignore the non-French-speaking children and teen-agers' language skills. This lack of recognition does not occur in a neutral way, but rather a negative one, strongly repressed and usually perceived by the victim as a violence which must be dominated to have a successful academic experience. Only a few champions win this hard-fought struggle: four out of a thousand Turkishspeaking pupils schooled in France manage to get an advanced degree.

The highest state authorities have paradoxically commissioned this educational system which refuses to take any account of its actually plurilingual pupils to produce bilingual pupils and bring up their current poor level in the mastering of modern languages. Bilingualism is a fantasy which takes its roots in the hierarchical and ideological representation of languages: the counselor of the employment center will advise an Arabic-speaking job-seeker to wipe out his/her command of Arabic of his/her CV and to mention only his/her proficiency in English and Spanish under the pretext that this will have a negative impact on the potential employer. As if Arabic could not represent a fantastic professional as well as cultural asset! As if the French business system had no interest in the Arab world!

Let us also quote the school contract of a secondary school integrating children coming from a poor social background or migrant families. This document was signed by the academic authorities and states that one of the objectives of this school is to "develop the international mobility of its pupils and strengthen the learning of languages". It never takes into account the fact that two-thirds of its number of pupils crosses the sea every summer to spend their holidays in their parents' native country and that $70 \%$ of these children speak and receive every day at home another language which is not French. But this mobility is once again a fantasy of the monolingual educational actors who favor European countries and languages, mostly English and French, which represent assets in the labor market. 
And yet, the educative and administrative staff of this school is more or less aware of the discriminatory status resulting from this standard sort of ignorance. It is however never fully admitted par the apparatus of the ministry of the national education which discriminates heavily the non-French-speaking children who consequently suffer from school failure and cannot consider post-graduate studies. The fact of having no scientifically or institutionally confirmed statistics (the reasons will be given further on in this paper) makes such a statement very risky: one could be accused of getting rid of the safe basics of knowledge to adopt a hazardous ideological and political point of view. However every decent investigation led in the French education system of the structures integrating pupils with learning difficulties will inevitably underline the non-French-speaking feature of the left-behinds, these latter not being necessarily the foreign people or immigrants corresponding to the definition given by the National Institute of Statistics (INSEE) which requires the fact of one or both parents being born in a foreign country. The connection with migration may be remote and go back to two or three generations and thus make them even more invisible. Finally one must insist upon the near absence of investigation and statistics about the schooling of Traveller children, this expression being an administrative neologism used partly to represent Tzigane, Sinti, Roma, Yenishes and Gipsy populations. Their illiteracy rate is impressive, the schooling of their children is rare and when it is effective, their evident plurilingualism is very rarely taken into account even though these specific language skills are one of the dominant factors of the economical, social and cultural life of these groups.

The last PISA report indicates that the weakest pupils of our educational system have a very low level and that this level gets lower and lower every year. In France there is a huge discrepancy between the performances realized by the pupils coming from upper/low socio-professional categories and pupils from migrant families and others. The French school system, although regularly blamed for its failure rate feels inclined to highlight an unanswerable statistics: children from migrant families succeed better than children from non migrant families of the same socio-professional category because their parents deeply believe in the necessity of upward mobility and integration in the social majority.

This is true provided they do not remain stuck in the dregs of those socioprofessional categories but this is unfortunately frequently the case, this being both the cause and the consequence of their academic failure. All of the studies made in France about this subject adopt the same point of view, exclusively correlating the academic failure to the family social situation, never taking into account the part the language played in the selection of the pupils. The result of this total blindness is the absolute lack of effective pedagogical supports for the use of these populations. Indeed, if the school system has no impact on the socio-professional comfort 
of the families involved, it could however be able to act upon its own ability to teach and evaluate to help these pupils to achieve an academic success.

We are talking of the non-French-speaking population by and large, not just the first generation of immigrants, that is to say people whose maternal or familial language is not French. This category of population is totally absent from any sort of official school statistics. This is the case of the Traveller children mentioned above.

So the first question to be asked is obvious: why does the French school system, so fond of statistics on any subjects about its own institution, has never clearly stated any relationship between the fact of not speaking French and academic failure? Why has it never led any investigation on the languages spoken by the pupils, on the link between these languages and French as a langue de scolarisation? Why is it that in a society built for a large part on immigration with the long-standing integration of populations with linguistic and cultural specificities that speaking a foreign language, a dialect or a certain version of French has always been represented by the French school system as an unmentionable sort of handicap to be overcome, a disgrace to be hidden, one could even add a sin to be atoned for. Why have these people who also live in a language which is not the French language never been part of a collective school project dedicated to community harmony, instead of that the only objective is a self-inflicted mutilation, a final and desperate amputation? Are we entitled to say that French, like God in the Old Testament, is an exclusive and jealous language which would be reluctant to any other form of language? Would it mean that to honor the true God of the republican temple definitely requires stopping revering more or less illicitly the original idol?

One may be surprised by those questions but they express what the actors of the educational system really think. No need to quote all the ignorant and definite remarks we, the authors of these lines, can hear daily in our professional meetings. We have to face the question of our pupils' own language and the way French can be taught from their own language. We have to overcome the fact that the system blindly refuses to accept it and work on the initial and ongoing training of teachers, develop scientific studies on this issue and have a clearly asserted political management. For the moment none of these conditions is set into motion or even hoped for by the educational actors, the authorities, or even the constitution, but we will deal with that point later on.

Let us give a very recent example (2010) of what we have just been mentioning. It comes from a document produced in a secondary school for a twelve-year-old pupil and his Turkish family. It is a sort of contract signed by the family and the educational team the objective of which is to help a pupil overcome his/her learning difficulties by organizing an adapted educative support (PPRE : programme personnalisé de réussite educative*). In this precise case, the learning difficulties were mostly a lack of written skills in French (oral skills are never evaluated as such in French 
schools). The diagnosis had been based mainly on bad marks but lacked a scientific approach or a technical analysis. The advice given by the headmaster to the Turkish family was "to speak French at home". All the school teachers, altogether twelve of them teaching different subjects thus proceeded into compelling the family to apply this measure. Not less than fifteen adults in the school were aware of the document but none of them expressed any indignation or at least any surprise. That means that each of them was convinced that a human being can only use one language and that giving up Turkish was the only solution to improve the mastering of the French language. Please, do try to imagine the inward struggle this young boy had to fight: to succeed academically speaking would mean to give up his fatherly and motherly love, to repress his own parents, to abandon his mother tongue, the language of his heart, as it was a shameful process? Try to imagine also the legitimate anger of this family and their friends towards such a claim which is totally contrary to the European language policy to which modern Turkey subscribes to with a certain success (a high growth rate, a commercial aggressiveness and a growing influence on the global market). For instance we regularly notice that the people affected by these decisions are aware of the different educational measures in Europe and have a very clear point of view as far as strategies about their children's plurilingualism are concerned.

The terrifying statistics given by the Délégation générale au français et aux langues de France give evidence: only a quarter of the people who have inherited a language different from French pass it on to their children. Many of these parents refuse to speak their own language with their children hoping that thanks to this sacrifice they will increase their chance of an academic and social success.

This issue initiates many questions:

How can the actors of the school system be entitled to interfere in the family private sphere? How can they seriously consider the fact of enticing people to abandon their mother tongue, their culture, their identity because of an educational indictment? Why did not they ask themselves if these parents could read and understand the document before signing it? Why was there no assessment of the pupil's skills in the Turkish language? Why was it not suggested to improve his knowledge in an appropriate way thanks to a language and culture or origin course (LCO* : cours de langue et culture d'origine) or the National Center for Distance Learning (CNED*: Centre national d'enseignement à distance)? When this pupil is 16, at the end of compulsory education, he will have to validate the Common Base of knowledge and skills like any other French pupil. Why should he have no choice and validate one of the languages taught in his school, that is to say English, German or Spanish instead of having the opportunity to validate the level A2 of the European Framework of Reference for Languages (CECRL: Cadre européen de references pour les langues vivantes) that he no doubt masters easily. Why has the Common Base of knowledge and skills not taken into account the mediation skills from the European Framework 
of Reference, this is undoubtedly the skill to be developed and assessed for plurilingual pupils. Why does the school system refuse to consider Turkish in the collège as a foreign language contrary to the lycée? One of the most paradoxical elements of the French school system concerns the number of languages which can be assessed for the baccalauréat (an exam eighteen year old pupils take at the end of secondary school): 44 languages altogether mentioned in the National Bulletin of the National Education (BOEN: Bulletin officiel de l'Education nationale)!

Let us go back to our previous situation: why, despite many counter examples, regard a French-speaking family as a sine qua non condition of an academic success? Speaking French at home does not mean that speaking a vehicular language in everyday life is enough to build the official language necessary to learn the different subjects taught at school (langue de scolarisation)? Many pupils from French-speaking families from a poor socio-professional background unfortunately fail at school, too. In short, one is entitled to wonder how the actors of the school system consider the learning and teaching of French when writing such an advice on an official document.

Half a millennium of political and cultural history has added different strata to the dominant model of the monolingualism à la française, a fundamental element of the national culture shared by the public opinion and closely linked to the educational and traditional culture. One will easily understand that the description of its data structure which covers the field of the republican national identity will be the theme developed in the following pages. This monolingualism being a sort of imperialism, no wonder it works the other way round as soon as it crosses the border of the Republic. Indeed France stands up very strongly for plurilingualism on the international level, refusing the hegemony of the globish and fighting for the use of French in the European and international institutions. For example, every French civil servant going to Brussels or Strasbourg receives an official booklet stating the defense of French as a language to be used in every translation. Whatever his mastering of the other languages of the European Union, he is reminded that he has to express himself in French whenever possible. That is why France initiated and signed the UNESCO programmes favoring improvement of research on cultural policies such as cultural pluralism and cultural exception including the latest Convention for the Safeguarding of Intangible Cultural Heritage which considers languages as a vehicle of the intangible cultural heritage. We can also quote the Convention on the Protection and the Promotion of the Diversity of Cultural Expressions and the fourteenth paragraph of its introduction: recalling that linguistic diversity is a fundamental element of cultural diversity, and reaffirming the fundamental role that education plays in the protection and promotion of cultural expressions. An important budget monitored by a steering committee is allotted yearly to the network of embassies and lycées français -the second network in the world, the Vatican being number one-, to promote the French culture and the learning of French. 
However, France considers monolingualism in the strict sense of the word on its own territory and refuses to ratify many international texts protecting linguistic minorities, such as the European Charter for Regional or Minority Languages and yet authorizing candidates to take Corsican, Catalan, Occitan or Breton as an option for the baccalauréat or opening higher education departments and competitive recruitment examinations to teachers of these options.

These relatively recent and marginal subjects were conceded to linguistic and cultural minorities by the Republic as the outcome of the struggles in the late $70 \mathrm{~s}$ whereas it had previously kept eradicating them by means of an aggressive school policy which established the exclusive monolingualism as a single standard. Nor does France ratify the article 30 of the Convention on the Rights of the Child which tends to make of the language spoken at home one of the human rights:

In those States in which ethnic, religious or linguistic minorities or persons of indigenous origin exist, a child belonging to such a minority or who is indigenous shall not be denied the right, in community with other members of his or her group, to enjoy his or her own culture, to profess and practice his or her own religion, or to use his or her own language.

Nor does it ratify the protocol $\mathrm{N}^{\circ} 12$ of the European Convention on Human Rights or for that matter The Convention for the Protection of National Minorities or the article 27 of the Covenant on Civil and Political Right. How can this be explained? One needs to travel back in time to understand.

Historically speaking, it is easy to explain that French was born in a tiny part of the Ile de France area. Originally, several other regional languages were used on the present territory, the Picard or the langue d'oc also used in the Iberian world. The hegemony of the French language was consequently based on the suppression of the trans-European languages first, then the suppression of the regional languages, and finally the suppression of the migration languages. The adventures of the French language are closely linked to royalty and its centralizing tendency. It is a language of a regal nature which, from the edict of Villers-Cotterêt promulgated in 1539 by Francis $1^{\text {st }}$, dominates the administrative acts on the pretext that it would be easier to understand than Latin for the contracting parties. At the same time, the king initiates the necessary institutions, such as the Collège de France to fight against the medieval Université de la Sorbonne and contributes to the birth of a French literature which would be charged with building a language worthy of competing with the Latin letters, the same way these latter did with the Greek ones.

This is precisely the objective of the Pléiade. Its manifesto is the famous text by Joachim Du Bellay, Défense et illustration de la langue francaise. The march of the monarchy towards absolutism will be accompanied by the creation of a single authority, the Académie française. French remains the only language in the world to be a State 
affair governed by laws and decrees. For instance, in 1976 René Haby, minister of education, issued a decree requiring orthographic tolerance for the evaluators of examinations and competitive examinations much favored in France. The last reform of the orthographic system was published in the official Journal in 1990 but neither the ministry of education nor the teachers working for it seized the opportunity. The founding Fathers of the Republic capitalized on the fundamentally regal aspect of the French language initiated during the Renaissance adding a universalistic dimension which remains today consubstantial to the language of the Declaration of the Rights of Man and of the Citizen. This French language which was also for a large part of the $18^{\text {th }}$ century the language of the European intellectual aristocracy, the language used by the authors of L'encyclopédie and the Philosophes who inspired the French Revolution of 1879, clearly becomes for the revolutionaries the melting pot of republicanism, the basic tool of law and science which will shape consciences originally built on superstitions, local cultural specificities and other patois leading to resistance and counter-revolution. French becomes the language of la Raison, the paradigm of precision, concision, clarity conducive for the deployment of rationality and knowledge. It was even thought that this language was the solution for oppressed peoples to find the way to emancipation. This fantasy - language as a civilizing experience- will be used as an excuse as well as the tool of the colonial expansion.

The present school system is still founded on its ideological base, on ideals from the Lumières of the minister Jules Ferry who, under the Third Republic initiated both compulsory schooling and teacher training colleges covering the entire territory so that teachers could learn French before teaching it (most of them could not speak it) to train citizens and future soldiers to be able to understand orders. In France, the French language remains a major emblem of the republican identity.

Far from being considered like a language among many others in Europe, French is still considered by the French as a major component, the skin of the nation body. This is clearly stated in the first two articles of the Constitution of the Fifth Republic from 1958 in line with the Contrat Social written by Jean-Jacques Rousseau: «France shall be an indivisible, secular, democratic and social republic». The symbolical body of the people any more than its language cannot be subdivided, thus the French republic does not recognize any minority. This is under this principle that it would be illegal for French schools to compile and store nominative data on ethnic or linguistic bases. That is why we have no precise official data on what becomes of migrant children and Traveller children in terms of schooling and vocational studies. This interdiction results in a poor scientific knowledge of their future and the impossibility of studying cohorts in real time. European institutions regularly accuse France of not producing the data required by the antidiscrimination scope of work. Just read the last report of the ECRI dated from June 2010, the fourth monitoring cycle 
of France. This group of experts from the Council of Europe asked the French authorities to acquire the necessary legal instruments to fight against discrimination, to protect and promote minorities. We have already given the list of these unratified international tools.

The French authorities stated that France's position concerning these instruments remains unchanged since the ECRI's last report. They explained that the constitutional principles of the indivisibility of the French Republic and the oneness of the French people, of which no section may claim for itself the exercise of national sovereignty, prevent the recognition of collective rights or any group, whether defined by a common origin, culture, language or belief. According to the authorities, the notion of "minorities" is alien to French law.

So, one of the greatest republican taboos is this extraterritorial identity on a monolingual continent. Under the pretence of not stigmatizing them, of treating them as equal, generations of non French-speaking pupils are rejected for their identity on a violently binary mode: either they get integrated by giving up their own identity or they remain forever classified as strangers.

The top priority of article 2 of the Constitution of the Fifth Republic "on Sovereignty" is the language - "The language of the Republic shall be French", the national emblem (the blue, white and red tricolor flag) comes second to finish with La Marseillaise, the national anthem.

It is easy to understand that in a confused fantasy, any mistake committed against the language is more or less an anathema against the national identity and that la maîtrise de la langue française is the first pillar of the Common Base of knowledge and skills to be validated at the end of the compulsory education to obtain their future citizenship.
Gaining access to all areas of knowledge and developing skills will depend on the ability to read, write and speak. French. The French language is the main instrument for equal opportunities, freedom of citizens and civility, as it allows oral comprehension and expression, interaction, written comprehension and expression in various situations and makes it possible understand and express one's rights and duties. Pupils will master the French language and develop a clear and precise oral and written expression, through the teaching of French but also that of other branches of instruction. Teachers and members of the teaching community are responsible for this priority school mission. Regular reading of French-language literature is a major instrument in acquiring a good command of the French language.

The grammatical irony of the expression "maitrise de la langue" over employed in the school rules with its ambivalent "de" is not often perceived and must be explained: everybody thinks that it means that the French citizen controls the language whereas in fact it is the language which gives him/her his/her experience of the world. And this is just a minor ambiguity: what it does not say is the result of a deep misunders- 
tanding between school and the poor families enrolled. When we say LA langue, what sort of French language are we talking about? Certainly not their language, a language used to meet their neighbors, to find their way around the town or to play in the playground, a vehicular language for an everyday life shared with their pairs but rather a language of education, used to practice more and more complex learning strategies.

In France, French is still considered as being something more than just a language, as if it was a sort of political object. The media regularly show France as the scene of celebrations and passionate debates about their language. The French identify a nation to its language and its culture; it is very difficult for them to realize what plurilingualism is although it is a world-wide accepted fact, they still consider it as a series of fragmented monolingualisms. For them, bilingualism is a kind of double monolingualism without any bridge between the codes; they do not understand that it is possible to develop skills of different levels of the European reference framework in the two languages. When taken separately, every language is conceived as having to be learnt as a whole. The fact that one can develop strategies to learn a language and operate metalinguistic transfers, or implement intercomprehension between neighboring languages or for example understand texts written in Romance languages thanks to Latin or modern Greek thanks to Ancient Greek, all this remains largely ignored from school or more generally speaking from those who, as minorities on the French territory daily experiment the fact of living in a world made of several languages. The inhabitants of the Overseas Departments and Territories are the only one to live in a plurilingual environment. Let us take as an example the intricate specificity of Creole and French in the French Indies where speakers of indigenous languages switch from one language to the other, unable to produce Creole without any French.

On the contrary, on the metropole, the Franco-French vision of the language shared by the school system is more or less like Obelix's menhir in Asterix: a monolith and a monument. People consider French as a massive language with its rules engraved on an ever-lasting marble, equally dense, with perfectly superimposed strata of oral and written versions, identical phonological or lexical representations from Swiss to Quebec through Benin or gypsy caravans. There is no place for the study of variation whether sociolinguistic or geographic in the conception of the Common Base of knowledge and skills or in the French curricula.

The implicit model evoked but the "LA" of la langue française is never clearly stated: what sort of French is expected from children at school? From which social category? From which Paris sector? The French spoken in the media? The French spoken by the experts who teach it? In the present dominant conception, this inalterable object of worship never changes throughout history and thus can never be considered as an issue nor raise questions or initiate research.

Indeed, France has imported parts of the Common European Framework of References (the eight key competences for each stage of learning and on a life-long basis) 
in the seven pillars of the Common Base of Knowledge and Skills for the compulsory education without respecting the logic of the specifications at the origin of this proposition. As usual, French is traditionally not considered as language. Judging by the items of the palier 3 (the end of the compulsory education) for la maitrise de la langue francaise, it is clear they have nothing to do with the linguistic criteria of the European Common Framework of Reference. However they have been considered as the key to the national school habitus and can be read as the framework of "professional pupils". Indeed if French was considered as a language, it would be assessed like a language and there would be no difference between competence 1 (maitrise de langue française) and compétence 2 (speaking a modern foreign language).

Many well-educated French people are convinced French could be taught the same way it was taught a century ago, using the same teaching techniques, as if University had not produced anything during this period, as if there had been no progress as far as knowledge is concerned, as if the language itself had not changed. The myth of the golden age when every citizen mastered the formidable written skills at the end of primary school is still prevalent despite all the scientific studies and the publications which prove the contrary. It regularly feeds the national drama of orthography fuelled with the technical irregularities of a somewhat erratic linguistic system which once again cannot but understood without a historical and geographical context.

\section{The teaching of French in the French school system: a major obstacle to the valorization of the pupils' multilingualism}

Oral French is not more difficult to learn than any other, it is a Latin language and as such is not more difficult to speak as Catalan, Romanian or Italian. However written French raises specific problems which do not exist in the other European languages especially as if taken as a whole in a continuum. There is a huge discrepancy between the oral skills used in a daily communication context and the necessary written skills to achieve an academic success.

It is necessary to explain why French started in the $12^{\text {th }}$ century with a sober phonetic medieval writing form to reach a complex sort of spelling and mute letters. French is an erudite language which was used by the intellectual clerks caste. During the last centuries of the middle ages they re-latinized the language overloading it of mute letters which had not other role than highlighting a Latin etymology. It is interesting to point out some mistakes. For instance, poi (poids=weight) which came from the Latin word of the same meaning pensum thanks to a regular phonetic evolution was falsely perceived as coming from the word pondus (laid [eggs]). This is why, six hundred years later, le poids is still written with an $s$ at the end because this etymological $s$, like the one of corps (body) from corpus has nothing to do with 
the $s$ of the plural. Before the invention of printing, professional copyists took the place of the clerks and as they were paid according to the number of lines they undertook a stretching of the words. The several attempts of the French Academy in the Classical period to regularize the bustling morphologies did not help because some of them were not made by experts who could understand their function; they remained as such with no logical link between them. Finally, writers and creators having never been interested by the issue, it is the printers who configured the present French orthography. Let us refer to the corpus of the most famous dictionary, the Petit Robert, to study the current situation.

The French language uses phonetically speaking 36 phonemes (the smallest segmental unit of sound, among which 16 vowel sounds). 24 letters from the Latin alphabet are used to transcribe these 36 phonemes, adding the $v$ and the $j$. French uses approximately 190 graphemes (letters our groups of 2 or 3 letters) to write these phonemes. Let us give a few examples among the most significant ones: we can write the sound [o] with 45 different spelling, the phoneme [i] with 44 different ones, the anterior $a 46$, the palatal a 16 , etc.

In fact, French is not as what we are made to believe a nicely alphabetical language like the Castilian but an ideographic one full of homophones(words like "poids/ pois (weight/pea); vert/ver/vers (green/worm/towards) which are pronounced in the same way, but are spelt differently and which do not have the same meaning). Its written form necessitates the appropriation of its metalinguistical categories. French is a multisystem made of morphograms (spellings which transcribe a grammatical category). The problem is that in French morphograms are not stable and one feature does not correspond to a single grammatical category. For instance, $s$ will represent the plural of the nouns (des pains), the second person (tu manges) or the first person (je prends) of a conjugated verb, the adverbs (toujours, jamais ). Sometimes, it will be pronounced, sometimes not. Besides, plurals will sometimes be indicated by an $x$ (which is a previous short way of writing the us which has been lost, chevaux becoming CHEVAS, then CHEVAUX= horses).

To conclude, the ways of spelling are logograms, that is to say that they are used to make a difference between words which have the same pronunciation. The word faim (hunger) is made of two phonograms $F / A I M$ which represent two phonemes plus the morphogram $M$ which links the word to others of the same family: famines, affamé, famélique (famine, famished, emaciated) plus the logogram FAIM to make a difference with fin (end) and feint (simulate).

It is easy to understand that learning to master all the mechanisms of written French takes time. That is why a lot of time was spent at school to learn to master French writing skills: about a half or a third of the classroom activities was dedicated to exercises with blanks to be filled in, rules and their exceptions to be learnt by heart and the most sacred of all the exercises, the dictation. Most of these ac- 
tivities were based on schoolbooks dating from the beginning of the $20^{\text {th }}$ century still mentioned nowadays. Il faudrait revenir au BLED ${ }^{1}$, les jeunes ne savent plus écrire"(young people can no longer write properly, we should do as in the good old times and use the BLED again). But the children of the time lived in a rural civilization mostly preoccupied by the changing of the seasons around the year and who consequently did not need a wide range of language to communicate about the main human activities or understand and read orders that would be given to them, in particular during their military service which would cover an extremely long period of time (five years in 1913) and which played an important part in the republican linguistic merger. Ultimately, one must not forget that if the people colonized by France throughout the world remember with a certain sort of cynicism having learnt that their ancestors were Gauls, it is not because the teachers sent to Dakar from the metropole thought Wolofs were genetically related with Celts but rather because they had been learning and then teaching this nonsense exercise after exercise, dictation after dictation.

This orthographic part of the written language has considerably been reduced and the current school elite's field of investigation is larger than before, in parallel with the hyper complex and globalized world they live in, notably as far as mathematics, science and techniques are concerned. Strangely enough, middle-class people still focus on these spelling skills, lured by longstanding representations probably because the teachers themselves remain obsessed with them. Although the issue of orthography has nowadays been supported by the new technologies and thus lost its impact, the school specificities and requirements about it has not changed at all.

Ever since its republican origin, the French education system recommends la maitrise de la langue française as a top priority. This constant demand is linked with the same sort of recurrent complaint about the level of pupils in French: it is getting lower and lower. In fact, this negative assessment mainly focuses on the spelling skills. They are so difficult to master that a good pupil needs twenty years to master them and that French teachers themselves master them when they start teaching them. As a result, la maitrise de la langue totally merges with the mastering of orthography; the teachers who assess the pupils' productions are unable to identify the skills acquired, the only thing they do is underline the pupils' fautes (mistakes). The word used in French is relevant, it represents the idea of "sin", the fact of being guilty. We could unfortunately compare French teachers with abusive parents: they have suffered when they were small to learn their spelling and consequently make their own pupils suffer from the same demand. Not enough actors of the French education system are able to recognize in their pupils' mistakes the linguistic impact of a learning

1 BLED: famous schoolbook of orthographical and grammatical exercises written in 1946 by Odette and Edouard Bled, French school teachers. 
in progress. Very few among them possess the necessary competence to make a scientific analysis of a pupil's oral or written production. Moreover there is a close link between a scientific knowledge of the language and a positive assessment: the greatest the ignorance, the worst the way of assessing, paying attention to details, form, and not to the meaning of the message.

All the actors of the educative system, as long as they have succeeded academically (both in secondary and higher education) have succeeded to master French spelling. Having become unconscious experts of the language, they take great care, most of the times as teachers, to act with their pupils the same way teachers acted with them in the past, and repeat the same chorus about a loss and a fall in the pupils' level. What is a shame is not only the ideological message they convey, but rather the fact of not being technically able to build scientifically founded didactics.

One of the specificities of the French education system seems to be the teachers' difficulty to understand that the learning process needs mistakes to progress. They can accept it as a concept but very rarely admit it in reality as far as the language is concerned. As for the French language, the expert because of his/her own experience with the written form expects the pupil to be perfect. The same pressure had been put on the teaching of foreign languages (things have been improving lately), which explain the poor results of French as a foreign language. Pupils did not dare speaking during the language lesson, being afraid of making mistakes. This cultural specificity of the French education system still persists, and the PISA results and analysis are a clear example of it: French pupils prefer not to give an answer rather than making a mistake. Their "no answer" rate remains high.

This history of education explains why French is never taught as a language except in a few classes d'accueil (CLA*) for non-French-speaking pupils but as a patrimonial objet to be transmitted like a literary capital. All you have to do to be convinced of it is read the French curricula of the secondary school; they are entirely made for French-speaking people having already a good mastering of the language and totally ignoring the progress made in language didactics during the last fifty years. The oral language is absent from the classroom: what strikes foreign people most when they visit French classes is the way pupils remain mute, or pupils who have at best a few seconds to answer their teacher, and not to express themselves. French teachers have not had any training in linguistics, or have only had a few courses on this subject. They take their professional exam on descriptive grammar, literary texts and literature, not on the language itself. People who study French as a foreign language (FLE) learn means to teach French as a language but have no training on the analysis of literature or the history of the language. Their course of study does not lead them to teach 
French in collèges and lycées but rather exclusively to feed the promoting system of French in foreign countries.

Another reason for the failure of non-French-speaking pupils or pupils coming from a poor social background is the following one: the common confusion between French as a subject and French as a language used to study other subjects - Français langue comme matière et le français langue des matières, to use the terminology of the experts of the Council of Europe on their Plateforme de resources et de references pour une education plurilingue et culturelle which is an extension of the European Common Framework of Reference for the Languages. In France, most of the teachers teaching a subject other than French honestly believe (and that is so comfortable!) that it is the French teacher who should always deal with the language issue whereas in fact every subject involves the language in its teaching/learning process. Indeed, the confusion between an analytic approach of the language and a functional one is very common in the French school, most of the educational actors thinking that it is vital to know all the metalinguistic specificities of the language before using it. For most of them, to learn a language is mostly to do grammar, spelling and vocabulary exercises. It is more or less as if one is expected before driving a car to be able to describe the chemical and physical nature of its parts, as well as the way it works electronically and mechanically. In fact, it is when using the language in various communication situations that we can learn it, thus stimulating all the language activities of the European framework: oral and written production both continuous and interactive, oral and written reception, mediation... The previous French curricula for the collège were based on the notion of discourse and communication and took it into account; as for the "new" ones dating from 2008 and despite a subtle preamble trying to establish an initial framework, to answer the political demand of an urgent return to the basics and to a certain "national" identity, they dilute and multiply analytic and descriptive details which put off the "learning by acting progress" too briefly anticipated.

In short, in a monolingual context which considers French as an ideological object of opinion and not of knowledge, school does not teach French as a language; instead of making it one of the objectives of learning, it constantly uses it in the educative process as the only necessary condition to have access to learning. That is why non-French-speaking pupils are also particularly put at a disadvantage, like all the French-speaking people from poor social background whose French is not the one used at school, or also like the gypsies from Perpignan who speak Kalo, Catalan and French. Far from teaching the French language essential for pupils to have an easy access to learning and to credit pupils with a scope of progress, the institution contents itself with demanding it and making it an unconquerable obstacle without giving any tools or building the necessary pedagogical situations for its appropriation. 


\section{The Copernican revolution of teaching and assessing skills: the emergence of the plurilingual pupil}

However, despite its cohesion force, the monolingual model we have been describing is starting to crack, mostly under the pressure of the teaching and assessing of skills, which makes people concentrate on the human subject and no longer on a transcendental external knowledge that could be transmitted without ever having to ask oneself who it is we are transmitting it to.

Some people tend to suggest that the introduction of the notion of skills in the school and university field is one more trick, somewhat crude, from the Capital to make of the child a future homo economicus, split into pieces right from the beginning the same way he/she will be split in the fragmented tasks of his future job. We do not share this point of view.

The progress made in language didactics will have to innervate the teaching of French so that French will no longer be considered as a sacred object but as a language and that people will finally understand that school failure is not a consequence of the pupils' lack of intelligence but of the school lack of intelligence, a school unable to understand or even get to know non-French-speaking pupils, a school unable to offer proper teaching aids.

The present education system starts focusing on the pupils' knowledge, trying to answer individual needs, to increase appropriate learning support in the collège as well as in the lycée. Educational actors whether they like it or not, will inevitably have to speak with the pupils, to ask them questions, to get to know them. For the moment, complete cohorts of mute pupils who have never been given the right codes suffer all throughout their school life, without any adult taking the time to speak with them and to assess scientifically their linguistic and academic skills with impartiality. But who in the school system could take this in charge? The answer is very simple, the teacher who already does it, that is to say the efficient teacher of the classes d'accueil (CLA) under the authority of the Centre académique pour l'accueil et la scolarisation des élèves nouvellement arrivés en France et des enfants du Voyage (CASNAV - Academic center for the reception and schooling of pupils newly arrived in France and Traveller children).

The promotion of plurilingualism together with the capitalized experience of the teaching of French as a second language or schooling language in the classes d'accueil for non-French-speaking countries decreed in the BO special of April, $25^{\text {th }}$, 2005 can really become a lever. The most efficient teachers of these classes can train their fellow teachers and write frameworks and texts on a national level about the reception and the schooling of all the pupils for whom French as a schooling language is a first and foremost a foreign language: non-French-speaking children, Traveller children, children from a poor social background. 
However, the ministry of education has been making progress these last years on the language issue: the introduction of the European Common Framework, of the certifications, the implement of bilingual classes and subjects taught in a European language, the use of the new technology in creative projects, intensive training periods during the holidays... A real revolution is taking place: a tool-box for the teaching of French as a language for pupils newly arrived in France will shortly be online on an official site.

If this project comes into being, this data bank will be the very first sign in the history of the French school system of the institutional double recognition of the pupils' plurilingualism and of French as a language. It will be the first step towards the creation of efficient and innovative weapons against the much complained about school failure.

CASNAV de l'académie de Besançon, Maryse Adam-Maillet, Odile Malavaux, Michael Rigolot

\section{FRENCH HYPERTEXT}

\section{Textes officiels français}

Constitution de la $\mathrm{V}^{\circ}$ République

Site du Ministère des Affaires étrangères: français et multilinguisme en Europe

Site du Ministère de l'Éducation nationale (Socle commun de connaissance et de compétence)

«La France sait-elle encore intégrer les immigrés?» «Bilan de la politique d'intégration en France depuis vingt ans» (Enquête INED/INSEE) avril 2011

Les défis de l'intégration à l'école (Rapport de la Documentation française) janvier 2011

\section{Histoire de la langue}

Ordonnance de Villers-Cotterêts par François I $^{\text {er }}$

Site de l'Académie française

Site de la Délégation générale à la langue française et aux langues de France

\section{Textes internationaux}

Convention sur la protection et la promotion de l'expression de la diversité culturelle (Unesco)

Convention pour la sauvegarde du patrimoine culturel et immatériel (Unesco)

Convention internationale des droits de l'enfant

Examens de l'OCDE sur la formation des migrants ; Combler l'écart pour les élèves immigrés

Politiques, pratiques et performances (OCDE)

Résultat du PISA 2009 : Synthèse (OCDE) 
124 RECERCA, 11. 2011. ISSN: 1130-6149 - DOI: http://dx.doi.org/10.6035/Recerca.2011.11.8 - pp. 107-124

\section{Textes européens}

Cadre européen commun de référence pour les langues vivantes

Plate-forme de ressources et de références pour une éducation plurilingue et interculturelle

Charte européenne des langues régionales et minoritaires

Charte européenne du plurilinguisme

Compétences clés pour l'éducation et la formation tout au long de la vie

Commission européenne contre le racisme et l'intolérance ; Rapport de l'ECRI sur la France (quatrième cycle de monitoring) 